\title{
The returns to investment in education: Some theoretical and empirical insights
}

\author{
Ukaj MIC ${ }^{\star}$, Mustafa Topxhiu RAHMIJE ${ }^{\star \star}$
}

\begin{tabular}{l}
\hline \multicolumn{1}{c}{ A R T I C L E I N F O } \\
\hline Article history: \\
Accepted April 2019 \\
Available online April 2019 \\
\hline JEL Classification \\
J24, I26, I20 \\
Keywords: \\
Human capital, Education benefits, \\
Education costs, Returns to \\
education
\end{tabular}

1. Introduction

Return to investment in education has started to be assessed since the late 1950s (Montenegro and Patrinos, 2014), and since then, the number of studies that have been dealing with this issue has increased exponentially. The results of these studies show that investment in education is profitable as to the direct benefits it brings to the labor market, such as: increase of active participation in the workforce, increase of employment prospects, increase of incomes, as well as by the large number of indirect benefits, such as poverty reduction, crime reduction, health improvement, increase of longevity, reduce of infant and mother's mortality, etc.

From a summary of the results of studies in a global scale, the return rate ranges between $8-10 \%$, being higher in developing countries. Estimates also show that women benefit more than men from additional education (in relative terms), while the highest rate of return brings primary and tertiary education, with an increasing trend for the tertiary (Montenegro and Patrinos, 2014; Patrinos, 2016).

One of the main concerns among researchers when evaluating the rate of return was the presence of endogeneity in education which is mainly the result of the impact of the innate abilities. Researchers have used different strategies to address this issue, however, there are still doubts among researchers regarding the appropriateness of these strategies.

In this study, a review of literature on the role of human capital will be made, beginning with the first attempts to explain its importance, the types of investment, the creation of models for empirical assessment, the problems during the assessing the rate of return to education, the efforts to address these problems, as well as summarizing some of the empirical studies.

\section{Some theoretical aspects on investing in human capital}

Human capital is one of the most important source that possesses each country. However, its importance has risen on last decades due to great technological changes, which systematically is changing the nature of work and required skills.

Efforts to explain the importance of investing on human capital were pretty early. One of the earliest references in regards to the importance of investing in human capital is considered the one by famous economist Adam Smith (1776), in his book - The Wealth of Nations, where the author draws a parallel between investment in machinery and investment in education. He emphasizes that an educated man can be

^ Fama College, Kosovo, E-mail address: micukaj@ hotmail.com, (M. Ukaj - Corresponding author), ${ }^{\star \star}$ University of Prishtina, Faculty of Economics, Pristina, Kosovo. E-mail address: rahmije.topxhiu@uni-pr.edu, (R. Mustafa-Topxhiu). 
compared to an expensive machine, which with its work manages to extract the investment made for it, within a reasonable time. The same, individuals investing in education are able to do jobs that are paid over the payroll of ordinary workers, and this difference enables them to compensate for all education costs (Smith 1998, p. 145).

Even though the role of human capital was known early on, its' interest has increased significantly only after World War II when it was observed that national income was growing much faster than the growth of traditional production factors: land, labor and capital (Schultz, 1961; Psacharopoulos, 2006). Schultz (1961) made an important step in solving this mystery, arguing that additional income was the result of human capital which was growing much faster than physical capital.

While it was noted that human capital was one of the factors influencing economic growth, the challenge was to find types of investing in human capital and methods of empirical assessment. According to Schultz (1961) and Becker (1964), the main forms of investment in human capital are: a) formal education; b) training at the workplace; c) migration and searching for new jobs; as well as d) health care. All imply an initial cost, and all is done in the hope that the investment will be paid in the future in the form of monetary and non-monetary benefits (Ehrenberg and Smith, 2012 p. 278).

All the above mentioned forms, play a special role, however, education and training are considered the most important investments in human capital investment (Becker, 1993, p.p. 17).

\subsection{Education as a component of human capital}

There are two competing theories about the role of education in the economy, particularly in the labor market: Theory of human capital by Schultz (1961) and Becker (1964), and signaling theory by Spence (1973).

According to the first theory, investment in education enhances the knowledge of individuals, thus affecting their productivity growth, therefore, employers reward their workers with higher salaries (Shultz, 1961; Becker 1964).

According to the signaling theory, education does not increase productivity, it only serves to show the existing productivity to the employers (Son, 2010), in order to help them select more productive workers. Education can play this signaling role because potential employers find it difficult to observe the worker's ability directly during the recruitment process (Borjas, 2013).

According to Adams, King, Pener, Bandelj, and Kanjuo-Mrcela (2017), empirical literature has proven that these theories do not exclude each other; on the contrary, they complement each other. Moreover, numerous studies have shown that education not only increases productivity and, consequently, employee earnings, but it also brings a range of other indirect benefits that are of great interest to the individual but also to society in general. These benefits from education have pushed individuals (families) and governments across the world to spend considerable sums of money on education.

\subsubsection{Education benefits}

Education benefits are divided into two main groups: monetary benefits and non-monetary benefits (World Bank, 2018). Table 1 summarizes some of the main monetary and nonmonetary benefits that individuals and society benefits from education.

Table 1: Monetary and nonmonetary benefits from education

\begin{tabular}{|c|c|c|}
\hline & Individual benefits & Social benefits \\
\hline Monetary & $\begin{array}{l}\text { Bigger probability of employment } \\
\text { Higher productivity } \\
\text { Higher earnings } \\
\text { Lower poverty }\end{array}$ & $\begin{array}{l}\text { Higher Productivity } \\
\text { More rapid economic growth } \\
\text { Poverty reduction } \\
\text { Long-run development }\end{array}$ \\
\hline Nonmonetary & $\begin{array}{l}\text { Better health } \\
\text { Improved education and health of } \\
\text { family } \\
\text { Greater resilience and adaptability } \\
\text { More engaged citizenship } \\
\text { Better choices } \\
\text { Greater life satisfaction }\end{array}$ & $\begin{array}{l}\text { Increased social mobility } \\
\text { Better-functioning institutions/service } \\
\text { delivery } \\
\text { Higher levels of civic engagement } \\
\text { Greater social cohesion } \\
\text { Reduced negative externalities }\end{array}$ \\
\hline
\end{tabular}

Source: World Bank (2018).

There are a large number of empirical studies that prove the undeniable role of education in all the benefits presented in table 1 (for these benefits see UNESCO, 2013, 2017, Psacharopoulos, 2014, Loichinger 2015, OECD, 2013). Researchers have been more focused on economic benefits, while non-monetary ones are more difficult to measure, nevertheless, there exist many studies that prove a large number of nonmonetary benefits. 


\subsubsection{Education costs}

Besides many benefits, education is associated with a range of costs, which can be categorized into two main groups: state (social) costs and individual costs.

State or social cost - are divided into two groups: 1) direct costs, referring to government spending on school's construction and maintenance, teacher payments and accompanying staff, equipment and ancillary materials, and other education-related costs, and; 2) indirect costs, referring to state losses in production, arising from not working of persons continuing education (Becker, 1993).

Individual costs are also categorized into three main groups: 1) direct expenses, including tuition costs and expenditures on books and other supplies; 2) forgone earnings, the income that a person would receive if he did not continue his education and starts work immediately; 3) psychic losses - education creates stress by causing tiredness to students (Ehrenberg and Smith 2012, p. 280). For some of the private and social costs of education see table 2 .

Table 2. Private and social costs of education

\begin{tabular}{|c|c|}
\hline Private costs & Social costs \\
\hline $\begin{array}{l}\text { Direct: } \\
\text { Fees, minus average value of scholarships } \\
\text { Books etc. }\end{array}$ & $\begin{array}{l}\text { Teacher's wages } \\
\text { Other current expenditure on goods and } \\
\text { services } \\
\text { Expenditures on Books etc. } \\
\text { Imputed rent }\end{array}$ \\
\hline $\begin{array}{l}\text { Indirect: } \\
\text { Forgone earnings }\end{array}$ & Forgone earnings \\
\hline
\end{tabular}

Source: Woodhall (2017). Cost benefit analysis in educational planning, p.p. 33.

\subsection{Cost Benefit Analysis: The Schooling model}

Any investment decision (including the decision to invest in education) must compare expenditures and incomes at different time periods (Borjas, 2013, p. 238). Therefore, the investor should be able to compare current costs with future earnings, to see if the investment is acceptable or not. For an investment to be acceptable, the benefits should at least cover the costs (Psacharopoulos and Patrinos, 2018). When making a decision to invest in education, individuals compare current costs to future incomes in order to maximize income or personal well-being. Meanwhile, when deciding on the amount of money dedicated to education, governments consider the efficiency of the use of public money and the well-being of society in general. In this study, only the decision of the individual to invest in education will be analyzed.

Usually, researchers start studying the investment in education by analyzing the income profile of an 18-year-old who has completed secondary education and has two options: to start work immediately by earning income; or to go to college, accepting direct and indirect expenses during education, in order to earn higher incomes after graduation compared to the high school students (see, for example, Psacharopoulos, 2014; Borjas 2013, p. 240; Ehrenberg and Smith 2012, p. 284).

Borjas (2013), in order to simplify the analysis, assumes that there is no training in the workplace, and that the acquired knowledge does not depreciate over time. These assumptions imply that the employee's productivity does not change from the moment he leaves the education, therefore his income will be constant throughout the life cycle, as a consequence, the income profile will be linear as in Figure 1 (Borjas, 2013, pp. 239). Figure 1 shows if a person decides to start work immediately, he will earn $w_{H S}$ income until retirement. If he decides to continue college, he sacrifices the current wage $w_{H S}$, at the same time accepts direct costs of schooling at the level $\mathrm{H}$, with intention that after completing the college, will be earning $w_{C O L}$ income throughout his life.

Figure 1: Potential Earnings Streams Faced by a High School Graduate

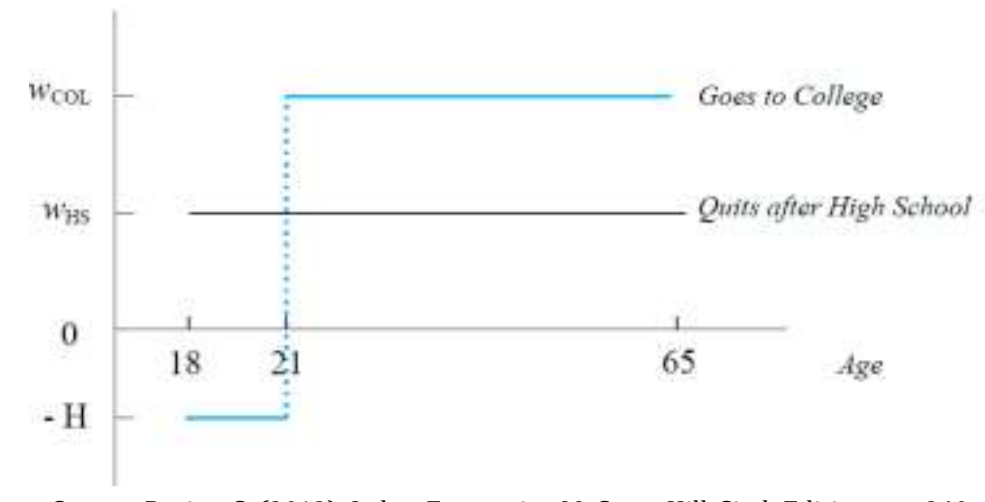

Source: Borjas, G. (2013): Labor Economics, McGraw-Hill, Sixth Edition, p.p. 240. 
"The decision on which earnings stream will the individual choose in Figure 1, depends on their present value

The present value of the earnings stream if the person decides to start work after he finishes high school can be expressed:

$$
\mathrm{PV}_{\mathrm{HS}}=w_{\mathrm{HS}}+\frac{w_{\mathrm{HS}}}{(1+\mathbf{r})}+\frac{w_{\mathrm{HS}}}{(1+\mathbf{r})^{2}}+\cdots+\frac{w_{\mathrm{HS}}}{(1+\mathbf{r})^{46}}
$$

Whereas, the present value of the income stream if the person decides to complete the college is:

$$
\mathrm{PV}_{\mathrm{COL}}=\underbrace{-\mathrm{H}-\frac{\mathrm{H}}{(1+\mathrm{r})}+\frac{\mathrm{H}}{(1+\mathrm{r})^{2}}+\frac{\mathrm{H}}{(1+\mathrm{r})^{3}}}_{\text {Direct Costs of Attending College }}+\underbrace{\frac{\mathrm{w}_{\mathrm{COL}}}{(1+\mathrm{r})^{4}}+\frac{\mathrm{w}_{\mathrm{COL}}}{(1+\mathrm{r})^{5}}+\ldots \ldots+\frac{\mathrm{w}_{\mathrm{COL}}}{(1+\mathrm{r})^{46}}}_{\text {Post-college Earnngs Sream }}
$$

Where $r$ represents the discount rate; $w_{\mathrm{HS}}$ is wage with high school; $w_{\mathrm{COL}}$ is wage with college.

As can be seen from equation 2, if a person decides to continue college, in addition to direct education costs $(\mathrm{H})$, he also waives $\mathrm{w}_{\mathrm{HS}}$ wages during this period and will have a shorter period of working life.

As mentioned above, the decision to invest or not in additional education will depend on maximizing the present value. In our case, the individual would continue the college only if the present value of income stream with college is higher than the present value of the income stream with high school" (Borjas, 2013, p. 240).

$$
\mathrm{PV}_{\mathrm{COL}}>\mathrm{PV}_{\mathrm{HS}}
$$

The discount rate ( $\mathrm{r}$ ), has an important influence to the decision on which level of education one chooses. Thus, if a person has a high discount rate (he values more current than the future money), chooses less education, and vice versa (Ehrenberg \& Smith 2012, p. 286).

\section{Estimation of the rate of return from education}

In general, empirical literature focuses on calculating two types of return rates from education: "the private return rate from investment to education - which compares the individual's costs and benefits from education; the social return rate from investment to education - which compares the costs and benefits the society receives from investment in education" (Psacharopoulos, 2014).

"In the literature, the assessment of the private return rate from education is mainly done through two methods: the full discounting method and the Mincerian earnings function. Although the first is considered to be more correct, however, due to its suitability, researchers preferred more the second one" (Psacharopoulos and Patrinos, 2018).

\subsection{Mincer earnings function (1974)}

This method is also known as the Mincer`s model, or the Mincer`s wage equation, referring to American scientist Jacob Mincer, who in 1974, while completing the Becker and Chiswick model (1966), with the additional component of the experience, created a model that became the cornerstone of a large number of worldwide studies (Heckman, Humphries and Veramendi, 2016).

Mincer (1974) made an adjustment of a wage function, adapting a function of log-wages (Lnw $\mathrm{w}_{\mathrm{i}}$ ), which uses years of schooling (S), years of experience $(\mathrm{X})$ and its square $\left(\mathrm{X}^{2}\right)$ as independent variables (Mincer, as cited in Psacharopoulos, 1995).

$$
\operatorname{Ln}\left(w_{i}\right)=\alpha+\beta_{1} S_{i}+\beta_{2} X i+\beta_{3} X_{i}^{2}+\mu_{i}
$$

Mincer, in the absence of experience data, proposed the potential experience calculated as actual age minus finished S years of schooling and years before starting school (Age - S - 6) (Card, 1998), while through the $X^{2}{ }_{i}$ is attempted to capture the rapid growth trend of earnings in the first years of career in the labor market, stabilizing them after a while, and the slight decline by getting closer to the retirement (Gunderson and Oreopoulos, 2010).

This model can also be adapted to assess the return rate according to the levels of education, by converting school years into series of dummy variables for the levels of education, like $D_{p}, D_{s}, D_{t}($ where $p, s$ and $t$, represent, primary, secondary and tertiary levels of education) (Montenegro and Patrions 2014).

$$
\operatorname{Ln}\left(w_{i}\right)=\alpha+\beta_{p} D_{p i}+\beta_{s} D_{s i}+\beta_{t} D_{t i}+\beta_{1} X_{i}+\beta_{2} X_{i}^{2}+\mu_{i}
$$

Estimate of the return rate through the Mincer earnings function is usually done using the Ordinary Least Square method (henceforth referred to as OLS) (Hoti, 2011). According to Blundell, Dearden and Sianesi (2001), OLS produces biased results of $\beta_{1}$ in equation (3) due to the correlation between $S_{i}$ and $\mu_{i}$. Thus, in the Mincer equation (3), the term error $\left(\mu_{i}\right)$ captures other unobserved individual factors that affect the income, but have an impact on the education decision, thus creating a correlation between schooling and error term (Harmon, Oosterbeek and Walker 2003). Some of the typical factors that may be related to individual characteristics, which may have an impact on wages as well as in education are: innate abilities, 
motivation, organizational skills, entrepreneurship, ability to manage time, willingness to work more etc., (Gunderson and Oreopoulos, 2010). Hence, people with higher levels of skills, motivation, etc., can gain more, regardless of the level of education, consequently, if such variables are excluded from the wage equation and are simultaneously correlated with education and income, the return rate coefficient does not represent the real effect of education in income, resulting in an endogenous problem.

Researchers have made efforts to address this issue by using different strategies, mainly in order to eliminate the impact of the innate abilities at the level of education that a person chooses; therefore, the return rate coefficient only captures the pure education effect in wages. In order to achieve this goal, three strategies are generally used:

1) The inclusion of direct measures of ability into the wage equation. This strategy consists in the use of the results of various tests that evaluate the skills of individuals, and their inclusion in calculations of education - wage relation. Through this approach, the educational coefficient is intended to capture only the effect of education, as it is controlled for innate abilities (Harmon et al., 2003; Borjas, 2013, p. 250).

2) The use of twins. Given that twins share genetics together along with other family circumstances as well as the district where they live in, it is thought that income differentials among these persons result only from differences in their education level, enabling an unbiased estimate of the return rate (Harmon et al., 2003; Buhler, Misted and Salvages, 2017).

3) Use of Instrumental Variables. This strategy consists in finding or building variables that affect the education but are not directly related to other factors influencing income, such as innate abilities, motivation etc., (Card, 1999, 2001; Harmon et al., 2003; Harmon, 2011). Researchers have used different variables as instruments in their research to assess the true impact of education in income. Card (1999) divides them into two main groups: The first set of instruments relates to the family characteristics of the individual being educated, known as the demand side instruments, such as: education of parents, family financial situation, female without sister, etc. Meanwhile, the second group includes instruments related to the institutional characteristics of the education system, known as supply side instruments, such as: education reforms, school proximity, minimum age of school dropout, quarter of birth, change of education system, tuition costs etc. For more explanation of these instruments, and some of their results see Card, $(1999,2001)$, Angrist and Kruger (1991), Peet et al. (2015), Harmon (2011), Badescu, Hombres and Villalba (2011), Harmon et al. (2003).

The use of the three strategies outlined above is based on the assumption that the assessment of the return rate through OLS overestimates the effect of education in income, assuming that a part of the return rate is the result of the innate abilities of individual. However, Montenegro and Patrinos (2014) conclude that endogenous treatment by using these strategies (especially Instrumental Variable), increases the rate of return, suggesting that OLS does not overestimate the rate of return, rather it underestimates it.

Harmon (2011), warns that "focusing on endogenous treatment, attempting to strip schooling as an exogenous variable, often requires the identification of assumptions that cannot be empirically tested, and consequently have not had any major success in the empirical plane". Moreover, most studies that have used different strategies to relax the assumptions or weaknesses of this model have achieved close results by it (Patrinos and Psacharopoulos 2010).

Therefore, in spite of the shortcomings mentioned in the literature, the Mincer model has served as a starting point for most researchers who have been involved with the return rate assessment and continues to be one of the most widely used equations in the economy.

\section{Review of empirical literature}

After establishing the theoretical basis by Schultz (1961) and Becker (1964), Jacob Mincer in 1974 made an empirical approximation to the theoretical model of human capital (Harmon et al., 2003) by providing a model which later became one of the most widely used equations in the economy. By using Census data of US in 1960, and data on potential experience, he found that return on investment in education was $10 \%$, while returns to experience was $8 \%$ (Harmon et al., 2003; Walker and Zhu 2001). Ever since then, many studies have been done, especially in developed countries, and there is an increasing trend of studies in developing countries, in particular, there is an increased interest in comparing the results between different countries.

Though, the number of studies contributed on this field have grown exponentially in recent years, to the extent of being hard to track (Psacharopoulos and Patrinos, 2018), we are going to present only the results from some of the most credible and most cited studies for assessing the rate of return to education on the global scale, those of Psacharopoulos and his colleagues from World Bank, Harry Anthony Patrinos and Claudio E. Montenegro. The series of publications of these authors started from Psacharopoulos in (1972), continuing with regular publications from Psacharopoulos (1973, 1981, 1985, 1994), later with Psacharopoulos and Patrinos (2002, 2004, 2018), and Montenegro and Patrinos (2014). Ongoing these studies have been enriched with assessment procedure, number of states and household surveys. The latter included 139 states and 819 harmonized household surveys, covering most of the world's countries.

Montenegro and Patrinos (2014) summarize the main findings of these studies, where the most important ones are: 1) private education benefits are generally positive and the average return rate across 
different countries is around 10\%; 2) education benefits appear to be higher in developing countries than in developed countries; 3 ) in general, the estimated benefits of education are higher for women than for men; 4) education benefits are higher at the primary and tertiary level, with an increasing trend for the latter; 5) education benefits have dropped modestly over time despite the rise in the average level of school achievement, suggesting that investment in education is a worthy investment (Montenegro and Patrinos (2014).

In general, studies dealt with return to education were focused on issues such as: private and social rate of return, the rate of return based on education level, return to education by gender, returns by economic development of countries, regions, etc. Following are some of the findings of these studies.

\subsection{Private and social rate of return to education}

According to Radelet, Lindauer and Block (2013), individuals gain more than society from investing in education (in monetary terms), for the fact that a part of their education expenses is taken over by the government. Thereby the individual receives all the benefits that education brings, while a part of his education costs is paid by the society, which through various taxes fills the state budget.

From Figure 2 (which represents the results of a study by Psacharopoulos and Patrinos (2004)), it can be noted that the private rate of return is higher than the social one in all levels of education.

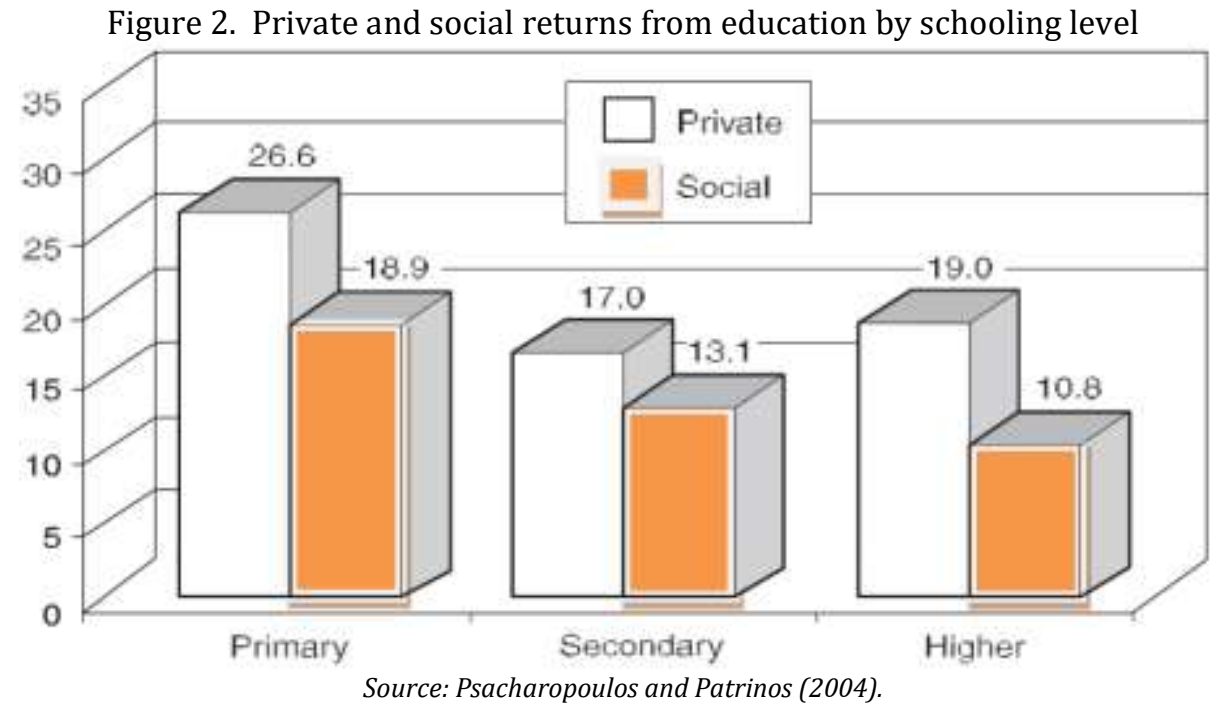

The same pattern can be seen in table 5, which represents the results of a study by Psacharopoulos and Patrinos (2018), where the private return rate is higher than social rate, regardless of the economic development of the countries. However, a number of indirect benefits have not been calculated here in, which, if they could be converted into monetary values, the social return rate could exceed the private one.

Several researchers have made efforts to evaluate many of indirect benefits of education in society. The results of these studies show that education has a significant impact on reducing poverty, improving health, reducing the deaths of children under the age of five, extension of life, increasing environmental care, reducing smoking and overweight, reducing marriages at young age, premature births, reduction of gender differences, increase of active participation in society, reduction of discrimination, etc. (for the results of these studies see Unesco, 2013, 2017, Psacharopoulos, 2014, Loichinger 2015, OECD, 2013).

\subsection{Private rate of return by education levels}

Overall, studies have shown a higher rate of return on investment in primary and tertiary education, with an increasing trend at the tertiary level (see for example, Psacharopoulos and Patrinos, 2004; Montenegro and Patrinos, 2014; Patrinos 2016). This pattern can be seen in table 3, which presents the results of a study including 139 countries with different levels of economic development, realized by Montenegro and Patrinos (2014). 
Table 3: The average rate of return by level of education, gender and region.

\begin{tabular}{lccccccccc}
\hline & \multicolumn{3}{c}{ Total } & \multicolumn{3}{c}{ Male } & \multicolumn{3}{c}{ Female } \\
\hline Region & Pri & Sec & Ter & Pri & Sec & Ter & Pri & Sec & Ter \\
\hline High Income & 4.9 & 6.6 & 11.1 & 3.3 & 7.5 & 10.7 & 7.2 & 5.2 & 12.3 \\
East Asia & 13.6 & 5.3 & 14.8 & 12.6 & 5.8 & 15.0 & 9.5 & 6.4 & 15.8 \\
Europe/Central Asia & 13.9 & 4.7 & 10.3 & 12.1 & 4.2 & 9.8 & 11.9 & 6.4 & 12.2 \\
Latin America & 7.8 & 5.4 & 15.9 & 7.9 & 5.3 & 15.7 & 8.7 & 6.5 & 17.4 \\
Middle East/N. & 16 & 4.5 & 10.5 & 12.7 & 4.3 & 10.2 & 21.4 & 7.4 & 13.5 \\
Africa & & & & & & & & & \\
South Asia & 6.0 & 5.0 & 17.3 & 4.7 & 3.9 & 16.6 & 4.8 & 6.2 & 23.3 \\
Sub-Saharan Africa & 14.4 & 10.6 & 21.0 & 12.5 & 10.1 & 21.0 & 17.5 & 12.7 & 21.3 \\
All economies & 11.5 & 6.8 & 14.6 & 10.1 & 6.7 & 14.4 & 13.2 & 8.2 & 16.1 \\
\hline & \multicolumn{3}{c}{ Source: Montenegro and Patrinos (2014) } & & &
\end{tabular}

When discussing about the level of education which pays off more, it should be noted that there are growing thoughts that speak of the extraordinary role of early childhood investment (for more about these thoughts, see for example World Bank, 2019; Heckman, 2008; Doyle, 2017; Doyle, Harmon, Heckman, Logue, and Moon, 2017).

\subsection{Private return rate by gender}

Regarding gender differences, various studies argue that females achieve higher rates of return compared to males (Psacharopoulos and Patrinos 2004, Psacharopoulos 2014, Montenegro and Patrinos 2014, Peet et al., 2015). According to Psacharopoulos and Patrinos (2018), females at a global level realize a higher rate of return compared to males by about two percentage points (see fig. 3).

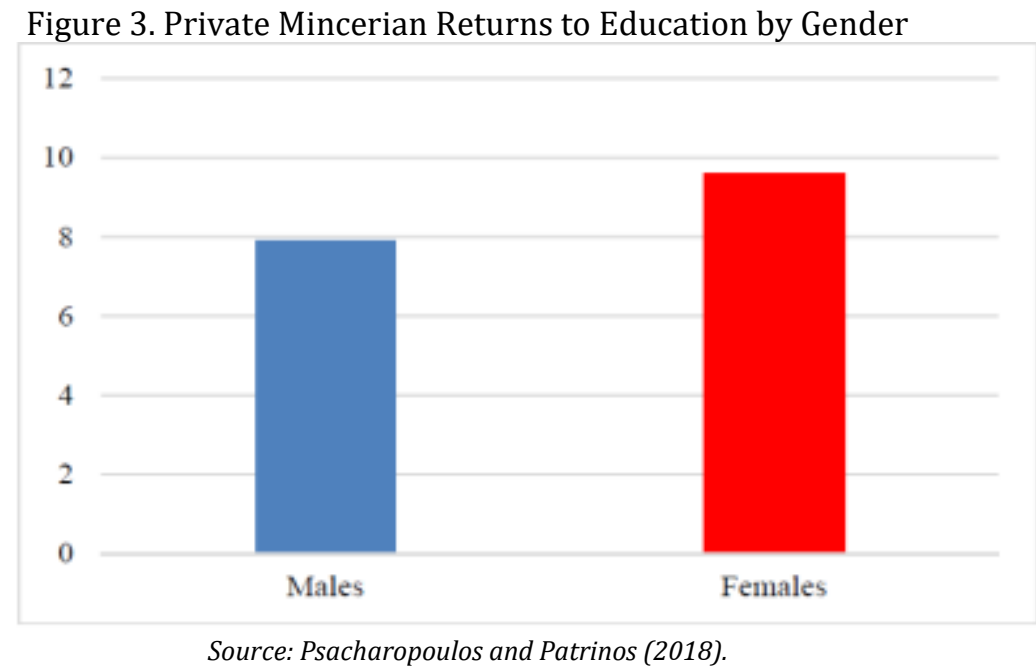

It should be noted that for the same level of education, females in absolute terms do not earn more than males. But the difference in income between a female with more education, compared to a female with less education, is greater than such difference between males (Perkins et al., 2013).

\subsection{The rate of return throughout years}

The studies of Psacharopoulos and Patrinos (2004), Patrinos and Psacharopoulos (2010) and Montenegro and Patrinos (2014), have shown a decreasing rate of return over the years, which was mainly attributed to the increase in supply of educated persons. This pattern can be seen in table 4 , where the relationship between years of education and the return rate from education results to be negative in most periods of time, except for the period 2011-2013, where the relationship is positive. According to Psacharopoulos and Patrinos (2018), the rising rate in recent years can be explained by the great technological changes, which have clearly increased the demand for a high level of skills. 
Table 4: Returns to Schooling and Average Years of Schooling by Period

\begin{tabular}{cccc}
\hline & Return rate & $\begin{array}{c}\text { Average years of } \\
\text { education }\end{array}$ & $\begin{array}{c}\text { Number of } \\
\text { surveys }\end{array}$ \\
\hline $1980-1985$ & 13.3 & 6.6 & 12 \\
$1986-1990$ & 12.7 & 8.1 & 23 \\
$1991-1995$ & 11.0 & 8.0 & 58 \\
$1996-2000$ & 10.1 & 8.8 & 109 \\
$2001-2005$ & 9.9 & 10.1 & 228 \\
$2006-2010$ & 9.6 & 10.9 & 238 \\
$2011-2013$ & 10.0 & 11.6 & 149 \\
\hline \multicolumn{4}{c}{}
\end{tabular}

\subsection{The return rate by the level of economic development of the countries}

Generally, studies have shown an oblique link between economic development and the rate of return on investment in education (Psacharopoulos and Patrinos, 2004, Montenegro and Patrinos, 2014). In lowincome countries, education is supposed to have a greater impact on pay differentials between people with different levels of education, considering the fact of deficit in the number of educated persons in these countries (Perkins et al. 2013). Table 5 shows the results of a study conducted by Psacharopoulos and Patrinos (2018), where it is noted that low and average income countries achieve higher return to education.

A.

B. Table 5: Returns by income and educational level (\%)

\begin{tabular}{ccccccc}
\hline $\begin{array}{c}\text { Per capita income } \\
\text { level }\end{array}$ & \multicolumn{3}{c}{ Private } & \multicolumn{3}{c}{ Social } \\
\cline { 2 - 7 } & Primary & Secondary & Higher & Primary & Secondary & Higher \\
\hline Low & 25.4 & 18.7 & 26.8 & 22.1 & 18.1 & 13.2 \\
Middle & 24.5 & 17.7 & 20.2 & 17.1 & 12.8 & 11.4 \\
High & 28.4 & 13.2 & 12.8 & 15.8 & 10.3 & 9.7 \\
Average & 25.4 & 15.1 & 15.8 & 17.5 & 11.8 & 10.5 \\
\hline
\end{tabular}

Source: Psacharopoulos and Patrinos (2018),

However, there are many underdeveloped countries where the rate of return is clearly below the world average (like Afghanistan, Iraq, etc.,), just like there are many developed countries that surpass it (USA, Japan, etc.,) (Montenegro and Patrinos, 2014). Moreover, some recent studies show a growing trend of return rates in developed countries, resulting from increased demand for high skills in these countries (Montenegro and Patrinos, 2014; Patrinos, 2016; David, 2014).

\subsection{Estimating the Returns to Education Using Samples of Twins}

Since the use of samples of twins is considered one of the most realistic methods that estimates the rate of return on investment in education (Psacharopoulos and Patrinos 2004), we will present some of the results of the studies that have applied this methodology.

One of the most cited studies in empirical literature, which uses income differentials among twins with different levels of education, is that of Ashenfelter and Kruger (1994). They took advantage of a festival organized in 1991 for identical twins in Ohio, USA, where they managed to interview 495 twins older than 18, out of 3000 sets of twins. The results of this research showed a return rate of investment in education of $12 \%$ to $16 \%$, which was higher than the average realized by using OLS $(10 \%)$, concluding that unobserved variables of skills do not overestimate the rate of return as it is thought, rather, the measurement error underestimates it. Also, some of the later studies that have used similar approaches show that OLS understates the rate of return (Behrmman, Rosenzweig and Taubman 1994; Rouse, 1998; Bingley, Christensen and Walker 2005). By contrast, Li, Liu and Zhang (2011), Isacsson $(1999,2004)$, through studies of this nature, conclude that the standard approach (OLS) greatly overstates the rate of return (see table 6). Whilst, Nakamuro and Inui (2012) and Bonjour, Cherkas, Hawkes, and Spector (2003) find that, to the extent that correction for innate abilities reduces the return rate, roughly, the rate of the return increases for the same percentage after correction for measurement error, resulting in a return rate approximately equal to the standard approach (OLS). 
Table 6: Summary of studies on identical twins

\begin{tabular}{|c|c|c|c|c|c|c|c|c|}
\hline & Source & Date & $\begin{array}{c}\text { MZ } \\
\text { Twins }\end{array}$ & Country & Gender & OLS & $\mathrm{FE}$ & FEIV \\
\hline $\begin{array}{l}\text { Ashenfelter \& } \\
\text { Kruger (1994) }\end{array}$ & $\begin{array}{c}\text { Princeton Twins } \\
\text { survey }\end{array}$ & 1991 & 147 & US & $M \& F$ & $\begin{array}{c}0.084 \\
(0.014)\end{array}$ & $\begin{array}{c}0.092 \\
(0.024)\end{array}$ & $\begin{array}{c}0.129 \\
(0.030)\end{array}$ \\
\hline $\begin{array}{c}\text { Behrman, et, al. } \\
\text { (1994) }\end{array}$ & NAS-NRC & 1973 & 141 & US & $\mathrm{M} \& \mathrm{~F}$ & $\begin{array}{c}0.094 \\
(0.011)\end{array}$ & $\begin{array}{c}0.035 \\
(0.004)\end{array}$ & $\begin{array}{c}0.101 \\
(0.012)\end{array}$ \\
\hline Miller et, al. (1995) & $\begin{array}{c}\text { Australian } \\
\text { Twins Register }\end{array}$ & 1985 & 602 & Australia & $\mathrm{M} \& \mathrm{~F}$ & $\begin{array}{c}0.064 \\
(0.002)\end{array}$ & $\begin{array}{c}0.025 \\
(0.005)\end{array}$ & $\begin{array}{l}0.048 \\
(0.010)\end{array}$ \\
\hline $\begin{array}{c}\text { Behrman \& } \\
\text { Rosenzweig (1994) }\end{array}$ & $\begin{array}{c}\text { Minnesota } \\
\text { Twins Register }\end{array}$ & 1993 & 720 & US & $\mathrm{M} \& \mathrm{~F}$ & $\begin{array}{c}0.113 \\
(0.005)\end{array}$ & $\begin{array}{c}0.104 \\
(0.017)\end{array}$ & $\mathrm{NA}$ \\
\hline Rouse (1998) & $\begin{array}{c}\text { Princeton Twins } \\
\text { Survey }\end{array}$ & $\begin{array}{c}1991-93 \\
1995\end{array}$ & 453 & US & $\mathrm{M} \& \mathrm{~F}$ & $\begin{array}{c}0.105 \\
(0.008)\end{array}$ & $\begin{array}{c}0.075 \\
(0.017)\end{array}$ & $\begin{array}{c}0.110 \\
(0.023)\end{array}$ \\
\hline $\begin{array}{l}\text { Bonjour et, al. } \\
\text { (2003) }\end{array}$ & $\begin{array}{c}\text { St Thomas } \\
\text { Hospital Twin } \\
\text { Register }\end{array}$ & 1999 & 187 & UK & $\mathrm{F}$ & $\begin{array}{c}0.077 \\
(0.001)\end{array}$ & $\begin{array}{c}0.039 \\
(0.023)\end{array}$ & $\begin{array}{c}0.077 \\
(0.033)\end{array}$ \\
\hline $\begin{array}{l}\text { Bingley et, al. } \\
\text { (2005) }\end{array}$ & $\begin{array}{l}\text { Danish Twins } \\
\text { Registry }\end{array}$ & 2002 & $\begin{array}{l}2185 \\
2000\end{array}$ & Denmark & $\begin{array}{l}\mathrm{M} \\
\mathrm{F}\end{array}$ & $\begin{array}{c}0.030 \\
(0.001) \\
0.037 \\
(0.001)\end{array}$ & $\begin{array}{c}0.005 \\
(0.001) \\
0.009 \\
(0.001)\end{array}$ & $\begin{array}{c}0.045 \\
(0.010) \\
0.044 \\
(0.008)\end{array}$ \\
\hline $\begin{array}{c}\text { Li, Liu \& Zhang } \\
\text { (2010) }\end{array}$ & $\begin{array}{c}\text { Chinese Twins } \\
\text { Survey }\end{array}$ & 2002 & 488 & China & $M \& F$ & $\begin{array}{c}0.084 \\
(0.006)\end{array}$ & $\begin{array}{l}0.027 \\
(0.012)\end{array}$ & $\begin{array}{c}0.038 \\
(0.018)\end{array}$ \\
\hline $\begin{array}{c}\text { Nakamuro \& Inui } \\
\text { (2012) }\end{array}$ & $\begin{array}{c}\text { Rakuten Twins } \\
\text { Survey }\end{array}$ & 2012 & 1371 & Japan & $\mathrm{M} \& \mathrm{~F}$ & $\begin{array}{r}0.100 \\
(0.007)\end{array}$ & $\begin{array}{c}0.045 \\
(0.012)\end{array}$ & $\begin{array}{l}0.093 \\
(0.045)\end{array}$ \\
\hline
\end{tabular}

Though it is considered by Psacharopoulos and Patrinos (2004), as one of the strategies that makes the most realistic estimation of the rate of return on investment in education, it has been criticized in the literature, for three main reasons: (1) does not indicate the reason for differences in education among twins (Harmon et al., 2003); (2) there may be other differences among twins, which cannot be observed by the researchers, which may be correlated with the decision on education, as well as with the income (Bhuller et, al., 2017); (3) even twins differ by skills level, and that they may have different discount rates (Sandewall Cesarini Johannesso, 2009; Borjas, 2013, p. 251).

Card (1999), after analyzing empirical literature, concludes that using twin studies to control for the innate abilities reduces the rate of return to education no more than $10 \%$. Moreover, Gunderson and Oreopoulos (2010) conclude that these studies yield almost the same results as those of the usual approach (OLS), when corrected for the error in measurement.

\section{Conclusion}

Since the introduction of modern human capital theory, researchers have consistently shown a high interest in assessing the role of education in the economy. Becker (1964) and Mincer (1974) established a framework in which the empirical work of many researchers would be based. Mincer (1974) offered an empirical model which, despite the many assumptions (often criticized in the literature), remains one of the most widely used model for assessing returns from investment to education due to its practicality.

In general, the study shows that investment in human capital is a profitable investment with multidimensional benefits. Some of the specific findings of this study are: the rate return from each additional year of education is around 10\%; female benefit more from investing in education than males do, in relative terms; the rate of return is higher in developing countries than in developed countries; primary and tertiary education bring higher rates compared to secondary education (there is a trend of increasing return on tertiary education).

One of the main concerns among researchers when evaluating the rate of return was that OLS overestimates the rate of return, mainly due to the impact of innate abilities. However, the use of various natural experiments in order to eliminate the impact of innate abilities, has in many cases resulted at a higher rate than the one through the standard approach (OLS), suggesting that OLS does not overestimate the return, rather the measurement error overestimates it.

One of the strategies that is believed to best estimate the rate of return (eliminating the impact of innate abilities at the level of education that a person chooses) is the one based on the use of twins samples (Psacharopoulos and Patrinos, 2014). However, the findings of many of these studies have resulted in a higher rate of return compared with OLS. 
Various studies have found many drawbacks in using natural experiments, including the use of twin strategies, creating doubts regarding the suitability of their use.

\section{References}

1. Adams, B. L., King, J., Penner, A. M., Bandelj, N., \& Kanjuo-Mrčela, A. (2017). The returns to education and labor market sorting in Slovenia, 1993-2007. Research in Social Stratification and Mobility, 47, 55-65.

2. Angrist, J. D., \& Keueger, A. B. (1991). Does compulsory school attendance affect schooling and earnings? The Quarterly Journal of Economics, 106(4), 979-1014.

3. Ashenfelter, O. \& Krueger, A. (1994). Estimates of the economic return to schooling from a new sample of twins. American Economic Review, 84, 1157-1173.

4. Badescu, M., D'Hombres, B., Villalba, E. (2011). Return to Education in Europian Countries; Evidence from the European Community Statistics on Income and Living Conditions (EU-SILC).

5. Becker, G.S. (1964). Human Capital: A Theoretical and Empirical Analysis with Special Reference to Education. New York: National Bureau of Economic Research.

6. Becker, G.S. and B.R. Chiswick. (1966). "Education and the distribution of earnings." American Economic Review 56(2): 358-369.

7. Becker, Gary S. (1993). Human Capital: A Theoretical and Empirical Analysis with Special Reference to Education. Chicago: The University of Chicago Press, Third Edition

8. Behrmman, J, R., Rosenzweig, M. R. \& Taubman, P. (1994). Endowments and the allocation of schooling in the family and the marriage market: the twins experiment. Journal of Political Economy, 102, 1134-1174.

9. Bhuller, M., Mogstad, M., \& Salvanes, K. G. (2017). Life-cycle earnings, education premiums, and internal rates of return. Journal of Labor Economics, 35(4), 993-1030.

10. Bingley, P., Christensen, K., \& Walker, I. (2005). Twin-based estimates of the returns to education: evidence from the population of Danish twins. unpublished paper.

11. Blundell, R., Dearden, L., Sianesi, B. (2001). Estimating the Returns to Education: Models, Methods and Results, Centre for the Economics of Education London School of Economics

12. Bonjour, B., Cherkas, L. F., Hawkes, D. D., \& Spector, T. D. (2003). Returns to education: evidence from U.K. twins. American Economic Review, 93, 1799-1812.

13. Borjas, G. (2013). Labor Economics, McGraw-Hill, Sixth Edition, p.p 235-287

14. Card, D. (1998): The Causal Effect of Education on Earnings; Center for Labor Economics, University of California, Berkeley Working Paper No. 2.

15. Card, D. (1999). The causal effect of education on earnings. In Handbook of labor economics (Vol. 3, pp. 1801-1863). Elsevier.

16. Card, D. (2001). Estimating the return to schooling: Progress on some persistent econometric problems. Econometrica, 69(5), 1127-1160.

17. David, H. (2014). Skills, education, and the rise of earnings inequality among the" other 99 percent".

18. Doyle, O. (2017). The First 2,000 Days and Child Skills: Evidence from a Randomized Experiment of Home Visiting.

19. Doyle, O., Harmon, C., Heckman, J., Logue, C., and Moon. S. (2017). Measuring Investment in Human Capital Formation: An Experimental Analysis of Early Life Outcomes; Labour Economics 45: 40-58

20. Ehrenberg, R. G., \& Smith, R. S. (2012). Modern labor economics: Theory and public policy. Routledge.

21. Ehrenberg, R., Smith, R. (2012). Modern Labor Economics, Theory and Public Policy, Eleventh Edition.

22. Gunderson, M., \& Oreopoulos, P. (2010). Returns to education in developed countries. Economics of education, 37-43.

23. Harmon (2011): Economic returns to education: What we know, what we don't know, and where we are going - some brief pointers; IZA, Bonn.

24. Harmon, C., Oosterbeek, H., \& Walker, I. (2003). The returns to education: Microeconomics. Journal of economic surveys, 17(2), 115-156.

25. Heckman, J. J. (2008). Schools, skills, and synapses. Economic inquiry, 46(3), 289-324.

26. Hoti, A. (2011). Returns for education in Kosovo: Estimates of wage and employment premia. South East European Journal of Economics and Business, 6(1), 71-84.

27. Isacsson, G. (1999). Estimates of the return to schooling in Sweden from a large sample of twins. Labour Economics, 6 , 471-489.

28. Isacsson, G. (2004). Estimating the economic return to educational levels using data on twins. Journal of Applied Econometrics, 19, 99-119.

29. Li, H., Liu, P. W., \& Zhang, J. (2012). Estimating returns to education using twins in urban China. Journal of Development Economics, 97(2), 494-504.

30. Loichinger, E. (2015). Labor force projections up to 2053 for 26 EU countries, by age, sex, and highest level of educational attainment; Demograpic reserch, V.32, Article 15, pp 443-486

31. Mincer, Jacob (1974) Schooling, Experience and Earnings, Columbia University Press for N.B.E.R., New Jork.

32. Montenegro, C.E. and H.A. Patrinos. (2014). Comparable estimates of returns to schooling around the world. World Bank Policy Research Working Paper Series 7020.

33. Nakamuro, M., Inui, T. (2012). Estimating the Returns to Education Using a Sample of Twins - The case of Japan RIETI Discussion Paper Series 12-E-076.

34. OECD (2013). Education Indicators in Focus, what are the social benefits of education?

35. Patrinos, A. H., Psacharopoulos, G. (2002). Returns to investment in education: a further update. The World Bank.

36. Patrinos, H., Psachoropoulos, G. (2010). Returns to Education in Developing Countries in P. Peterson, E. Baker and B. McGaw, eds., International Encyclopedia of Education (Volume 2). Oxford: Elsevier.

37. Patrinos, H.A (2016). "Estimating the return to schooling using the Mincer equation", IZA, World of Labor, Vol. 278. 
38. Perkins, D., Radelet, S., Lindauer, D., Block, S. (2013). Economics of Development, Seventh Edition; W. W. Norton \& Company New York.

39. Psacharopoulos, G. (1972). Rates of Return to Investment in Education around the World. Comparative Education Review, 16(1), 54-67.

40. Psacharopoulos, G. (1973): Returns to education: An international comparison; Elsevier, Amsterdam.

41. Psacharopoulos, G. (1981). Returns to education: an updated international comparison. Comparative education, 17(3), 321-341.

42. Psacharopoulos, G. (1985). Returns to education: A further international update and implications; Journal of Human Resources, 20 (4): 583-604

43. Psacharopoulos, G. (1994). Returns to investment in education: A global update. World development, 22(9), $1325-1343$.

44. Psacharopoulos, G. (1995). The profitability of investment in education: concepts and methods. Washington, DC: World Bank.

45. Psacharopoulos, G. (2006). The value of investment in education: Theory, evidence, and policy. Journal of Education Finance, 113-136.

46. Psacharopoulos, G., \& Patrinos*, H. A. (2004). Returns to investment in education: a further update. Education economics, 12(2), 111-134.

47. Psacharopoulos, G., \& Patrinos, H. A. (2018). Returns to investment in education: a decennial review of the global literature. Education Economics, 1-14.

48. Rouse, C. E. (1999). Further estimates of the economic return to schooling from a new sample of twins. Economics of Education Review, 18(2), 149-157.

49. Sandewall, Ö., Cesarini, D., \& Johannesson, M. (2009). The co-twin methodology and returns to schooling-testing a critical assumption.

50. Schultz, T. W. (1961). Investment in human capital. The American economic review, 51(1), 1-17.

51. Smith, A. (1998): The Welth of Nations; Elecbook classics, 20 Cambridge Drive, London SE12 8AJ, UK.

52. Son, H. H. (2010). Human capital development.

53. Spence, M. (1973). Job Market Signaling. The Quarterly Journal of Economics. 87(3): 355-374.

54. Unesco (2017/18). Global education monitoring report; Accountability in education: Meeting our Commitments.

55. UNESCO, (2013). Education transforms lives United Nations Educational, Scientific and Cultural Organization, Paris, France.

56. Walker, I., \& Zhu, Y. (2001). The returns to education: Evidence from the Labour Force Surveys.

57. Woodhall, M. (2017). Cost benefit analysis in educational planning.

58. World Bank (2018). World Development Report; Learning to realize education `s promise.

59. World Bank (2019). World Development Report; The Changing Nature of work, Washington, DC 